\title{
Antiaging Effect of Pine Pollen in Human Diploid Fibroblasts and in a Mouse Model Induced by D-Galactose
}

\author{
Gen-Xiang Mao, ${ }^{1}$ Ling-Di Zheng, ${ }^{1}$ Yong-Bao Cao, ${ }^{1}$ Zhuo-Mei Chen, ${ }^{2}$ Yuan-Dong Lv, ${ }^{1}$ \\ Ya-Zhen Wang, ${ }^{1}$ Xi-Lian Hu, ${ }^{1}$ Guo-Fu Wang, ${ }^{1}$ and Jing Yan ${ }^{1}$ \\ ${ }^{1}$ Zhejiang Provincial Key Lab of Geriatrics, Zhejiang Hospital, 12 Lingyin Road, Hangzhou 310013, China \\ ${ }^{2}$ Zhejiang Forestry Academy, Hangzhou 310023, China \\ Correspondence should be addressed to Guo-Fu Wang, zpklg@yahoo.com.cn and Jing Yan, zjicu@vip.163.com
}

Received 2 December 2011; Revised 10 February 2012; Accepted 14 February 2012

Academic Editor: Guilherme Antonio Behr

Copyright (C) 2012 Gen-Xiang Mao et al. This is an open access article distributed under the Creative Commons Attribution License, which permits unrestricted use, distribution, and reproduction in any medium, provided the original work is properly cited.

\begin{abstract}
The present paper was designed to investigate the effect of pine pollen against aging in human diploid fibroblast $2 \mathrm{BS}$ cells and in an accelerated aging model, which was established by subcutaneous injections with D-galactose daily for 8 weeks in C57BL/6J mice. Pine pollen $(1 \mathrm{mg} / \mathrm{mL}$ and $2 \mathrm{mg} / \mathrm{mL})$ is proved to delay the replicative senescence of $2 \mathrm{BS}$ cells as evidenced by enhanced cell proliferation, decreased SA- $\beta$-Gal activity, and reversed expression of senescence-associated molecular markers, such as p53, $\mathrm{p} 21^{\text {Waf1 }}, \mathrm{p} 16^{\mathrm{INK} 4 \mathrm{a}}, \mathrm{PTEN}$, and $\mathrm{p} 27^{\mathrm{Kip} 1}$ in late PD cells. Besides, pine pollen reversed D-galactose-induced aging effects in neural activity and inflammatory cytokine levels, as indicated by improved memory latency time and reduced error rate in step-down test and decreased concentrations of IL-6 and TNF- $\alpha$ in model mice. Similar to the role of AGEs (advanced glycation endproducts) formation inhibitor aminoguanidine (AG), pine pollen inhibited D-galactose-induced increment of AGEs levels thus reversed the aging phenotypes in model mice. Furthermore, the declined antioxidant activity was obviously reversed upon pine pollen treatment, which may account for its inhibitory effect on nonenzymatic glycation (NEG) in vivo. Our finding presents pine pollen as an attractive agent with potential to retard aging and attenuate age-related diseases in humans.
\end{abstract}

\section{Introduction}

Rodent chronically injected with D-galactose has been widely used as an animal aging model for brain aging or antiaging pharmacology research [1-4]. An increased level of advanced glycation endproducts (AGEs) is thought to account at least partially for the underlying mechanism as the AGEs inhibitor aminoguanidine (AG) could block most of the aging phenotypes in the D-galactose-induced mouse model [5]. AGEs are a heterogeneous group of reaction products that form between a protein's primary amino group and a carbohydrate-derived aldehyde group by reducing sugars, such as D-glucose and D-galactose, by nonenzymatic glycation (NEG) in vitro and in vivo [6]. Accumulating evidence indicates that AGEs exacerbate and accelerate aging process and contribute to the early phases of age-related diseases, including neurodegenerative disease, cataract, renal failure, arthritis, and age-related macular degeneration [79]. Moreover, AGEs and their precursors usually contain reactive carbonyl groups, which can be generated by the actions of reactive oxygen species (ROS) $[10,11]$.

As a kind of Chinese traditional medicine, pine pollen, which is the male spore of pine tree, has been used as a drug and food for thousands of years. Pine pollen has an effect in the treatment of different kinds of diseases such as colds, disease of the prostate, anemia, diabetes, hypertension, asthma, and rhinitis [12-14]. Pine pollen is collected artificially from Pinus massoniana Lamb., Pinus tabulaeformis Carr., and it has the characteristics of a single pollen source, pure quality, and is a stable component. Pine pollen powder, called "natural micronutrient storeroom," is rich in many kinds of bodydemanding amino acid, minerals, vitamin, enzyme, and flavonoids [12]. Although it is well proposed that pine pollen may have antiaging effect due to its various benefits on ${ }^{2}$ uman health, the direct supportive experimental evidence linking the drug with aging has rarely been reported so far. So, it is interesting to investigate whether pine pollen possesses any antiaging effect in vitro and in vivo. 
Here, the antiaging effect of pine pollen in vitro was firstly investigated by using the human diploid fibroblasts (2BS) cell line, which has been well characterized and widely used as a cellular senescence model [15-17]. Then, the accelerate aging model in mice induced by D-galactose was used to evaluate the effect of pine pollen against aging in vivo $[1,5,18]$. We treated a group of 5-month-old C57BL/6J mice daily with $\mathrm{D}$-galactose, D-galactose combined with various dosages of pine pollen $(500,1000,1500 \mathrm{mg} / \mathrm{kg}$, resp.), D-galactose combined with AGEs formation inhibitor AG, and control buffer for 8 weeks. At the end of the treatment, learning and memory abilities, serum and cerebral AGEs levels, indicators for antioxidant activity, and proinflammatory cytokines levels were determined. Our results demonstrated that pine pollen could retard the aging process in cells and mice thus presents pine pollen as an attractive agent with potential to retard aging and attenuate age-related diseases in humans.

\section{Material and Methods}

2.1. Reagents. Pine pollen was kindly provided by Zhejiang Yalin Biotechnology Co. Ltd. (Hangzhou, China), and was suspended with $0.5 \%$ sodium carboxymethyl cellulose (CMC-Na) before administrating. Bovine serum albumin (BSA), 5-bromo-4-chloro-3-indolyl-beta-D-galactoside (X$\mathrm{Gal}), \mathrm{D}$-galactose, and aminoguanidine hydrochloride (AG) were purchased from Sigma-Aldrich. Elisa kits for AGEs, interleukin-6 (IL-6) and tumor necrosis factor-alpha (TNF$\alpha$ ) determination were obtained from R\&D Systems, USA. Dulbecco's modification of Eagle's medium (DMEM), fetal bovine serum (FBS), and trypsin were obtained from Gibco, USA. Kits for malondialdehyde (MDA) assay and total superoxide dismutase (SOD) activity measurement were purchased from Nanjing Jiancheng Bioengineering Institute (Nanjing, China). BCA protein assay kit was from Pierce Chemical Co, USA.

2.2. Cell Culture. The 2BS cell line isolated from human fetal lung fibroblasts was originally established by the National Institute of Biological Products (Beijing, China) and has been well characterized and widely used as a cellular senes-cence model $[15,19]$. The cells are considered to be young at earlier than population doubling (PD) 30 and fully senescent at PD55 or later. The cells were grown in DMEM supplemented with $10 \%$ FBS, $100 \mathrm{U} / \mathrm{mL}$ penicillin, and $100 \mathrm{mg} / \mathrm{mL}$ streptomycin in an incubator at $37^{\circ} \mathrm{C}$ with $5 \% \mathrm{CO}_{2}$. The cultured cells were split in ratios of $1: 2$ or $1: 4$ when the confluence of the culture was over $85 \%$. The cumulative population doublings (CPDs) were calculated as $\log _{2}\left(D / D_{0}\right)$, where $D$ and $D_{0}$ are defined as the density of cells at the time of harvesting and seeding, respectively.

2.3. Cell Proliferation Monitoring. Cell proliferation was monitored using the XCELLigence system (Roche Applied Science, DP, Switzerland), an impedance-based nondestructive assay of cell proliferation. The presence of the cells on top of the electrodes affects the local ionic environment at the electrode/solution interface, leading to an increase in the electrode impedance. Increasing number of cells increases the impedance detected, displayed as cell index $(\mathrm{CI})$ values. The accuracy of this system has previously been validated for monitoring cell numbers over long periods of incubation [20]. Five thousand cells were seeded in $200 \mu \mathrm{L}$ of cell culture media in each well of a 16-well plate, in quadruplicate. Pine pollen was supplemented at a final concentration of $1 \mathrm{mg} / \mathrm{mL}$ and $2 \mathrm{mg} / \mathrm{mL} 24 \mathrm{~h}$ later, and the cells were cultured for an additional indicated time. Cell culture conditions were identical to that described above, and the cell proliferation was monitored over four days.

2.4. Senescence-Associated Galactosidase (SA- $\beta-G a l)$ Staining. 2BS cells grown in DMEM with or without pine pollen $(1 \mathrm{mg} / \mathrm{mL}$ and $2 \mathrm{mg} / \mathrm{mL})$ were stained according to a modified method of Dimri et al. [21]. The percentage of SA- $\beta$-gal positive cells out of the total number of cells was counted. Average percentages were obtained from three independent experiments.

2.5. Western Blot Analysis. 2BS cells were washed with iced PBS and then lysed with cell lysis buffer containing protease inhibitors cocktail (Cell Signaling Technology, Inc., USA). Protein concentrations were determined by BCA protein assay kit (Pierce Chemical Co.). Total $50 \mu \mathrm{g}$ of protein extracts were loaded and electrophoresed on 12\% SDS polyacrylamide gel and transferred to the nitro cellulose membrane (Bio-Red, USA). The membranes were subsequently probed with anti-p53, anti-p16 ${ }^{\mathrm{INK} 4}$, anti-p21 ${ }^{\text {Waf1 }}$, anti-PTEN and anti-p27 ${ }^{\text {Kip } 1}$ (Cell Signaling Technology, Inc., USA), and anti- $\beta$-actin monoclonal antibodies (Santa Cruz Biotechnology, Inc., USA), respectively. The secondary antibody used for detection was linked with horseradish peroxidase. The enhanced chemiluminescence (ECL) method was used to detect the conjugated horseradish peroxidase.

2.6. Animals and Treatment. Five-month-old C57 BL/6J female mice (Slaccas Laboratory Animal Co. Ltd. Shanghai, China), were randomly divided into six groups of ten each. After one week adaptation period, the animals were given daily one of the following preparations subcutaneously for eight weeks: (I) vehicle control; (II) D-galactose at $100 \mathrm{mg} / \mathrm{kg}$; (III) D-galactose at $100 \mathrm{mg} / \mathrm{kg}$ plus pine pollen at $500 \mathrm{mg} / \mathrm{kg}$ by intragastric injection; (IV) D-galactose at $100 \mathrm{mg} / \mathrm{kg}$ plus pine pollen at $1000 \mathrm{mg} / \mathrm{kg}$ by intragastric injection; (V) D-galactose at $100 \mathrm{mg} / \mathrm{kg}$ plus pine pollen at $1500 \mathrm{mg} / \mathrm{kg}$ by intragastric injection; (VI) D-galactose at $100 \mathrm{mg} / \mathrm{kg}$ plus $A G$ at $100 \mathrm{mg} / \mathrm{kg}$ by intragastric injection. Mice were sacrificed at the end of treatment, and sera, organs and tissues were immediately collected for experiments or stored at $-70^{\circ} \mathrm{C}$ for later experiments. Sera could be used for detection directly while tissue samples should be performed according to the following treatment.

Tissue Homogenization: tissue samples were weighed and homogenized in normal saline (NS) for studies, and homogenates of $5 \%$ were obtained. Tissue homogenates were sonicated two times at $30 \mathrm{sec}$, intervals. Homogenization and sonication were performed at $4{ }^{\circ} \mathrm{C}$. After sonication, 
homogenates for biochemical studies were centrifuged at $3000 \mathrm{rpm}$ for $10 \mathrm{~min}$ and at $12000 \mathrm{rpm}$ for $15 \mathrm{~min}$, respectively. Aliquots of the supernatants were used for the studies. The assayed parameters were expressed per mg protein, and protein content of the aliquots was determined by a BCA protein assay kit (Pierce Chemical Co.). All experimental procedures used in this study had been approved by the ethics committee within our hospital and all animal experiments had been performed in accordance with the ethical standards laid down in the 1964 Declaration of Helsinki. The authors who performed experiments had given their informed consent prior to the study and had followed "principles of laboratory animal care" published by the National Institutes of Health (NIH publication no. 86-23, revised 1985).

2.7. Step-Through Test for Acquisition of Memory. We used a step-down passive avoidance test to evaluate the learning and memory ability of mice according to the previous description [22]. Briefly, it is consisted of a transparent Plexiglas circular cage $(40 \mathrm{~cm}$ in height, $30 \mathrm{~cm}$ in diameter) with a grid floor and a circular platform ( $4 \mathrm{~cm}$ diameter) in the center. During the training session, animals were placed on the platform and their latency to step down with all four paws was measured. Immediately after stepping down on the grid, animals received an electric shock $(0.6 \mathrm{~mA}, 2 \mathrm{sec})$. Retention test sessions were carried out $24 \mathrm{~h}$ after training. Step-down latency on the test day was recorded as an index of inhibitory avoidance memory. A cut-off time of $300 \mathrm{sec}$ was set, and the number of memory errors during the $5 \mathrm{~min}$ was also recorded.

\subsection{Measurement of SOD Activity and Lipid Peroxidation in} Mouse. The activity for SOD in sera and brains was examined according to xanthine oxidase method provided by the standard assay kit (Nanjing Jiancheng Bioengineering Institute, China) as described [17]. The assay used the xanthine-xanthine oxidase system to produce superoxide ions, which reacted with 2-(4-iodophenyl)-3-(4-nitrophenol-5phenlyltetrazolium chloride) to form a red formazan dye, and the absorbance at $550 \mathrm{~nm}$ was determined. The values were expressed as units per mg protein, and protein concentration was determined by a BCA protein assay kit (Pierce Chemical Co.), where one unit of SOD was defined as the amount of SOD inhibiting the rate of reaction by $50 \%$ at $25^{\circ} \mathrm{C}$.

Lipid peroxidation was evaluated by measuring MDA concentrations according to the thiobarbituric acid (TBA) method as commercially recommended (Nanjing Jiancheng Bioengineering Institute, China). The method was based on the spectrophotometric measurement of the color produced during the reaction to TBA with MDA. MDA concentrations were calculated by the absorbance of TBA reactive substances (TBARS) at $532 \mathrm{~nm}$.

2.9. Protocols for Other Assays. ELISA assay for AGEs, IL6 , and TNF- $\alpha$ was carried out with commercial kits (R\&D Systems, USA) according to the manufacturer's protocol.
TABLE 1: The life spans of 2BS cells in CPDs, based on the actual number of cells harvested and seeded.

\begin{tabular}{lccccc}
\hline Group & Treatment & $\begin{array}{c}\text { Time of } \\
\text { transfer to } \\
\text { special } \\
\text { medium }\end{array}$ & $N$ & CPDs & $\begin{array}{c}\text { Average PDs per } \\
\text { week }\end{array}$ \\
\hline I & $\begin{array}{c}\text { control } \\
\text { Pine pollen } \\
(1 \mathrm{mg} / \mathrm{L})\end{array}$ & PD30 & 3 & $61.8 \pm 5.1$ & $2.2 \pm 0.2^{*}$ \\
II & $\begin{array}{c}\text { Pine pollen } \\
(2 \mathrm{mg} / \mathrm{L})\end{array}$ & PD30 & 3 & $60.5 \pm 4.7$ & $2.1 \pm 0.1^{*}$ \\
III & & & & & \\
\hline
\end{tabular}

Note. Cells were grown from PD30 in DMEM supplemented with pine pollen at $1 \mathrm{mg} / \mathrm{L}$ and $2 \mathrm{mg} / \mathrm{L}$, respectively. The cultured cells were split in ratios of $1: 2$ or $1: 4$ when the confluence of the culture was reached $70-80 \%$. CPDs (cumulative population doublings) were calculated as $\log 2(D / D 0)$, where $D$ and $D 0$ were defined as the density of cells at the time of harvesting and seeding, respectively. The last culture was defined as the subculture that could not be confluent in 3 weeks. Data were obtained from three independent experiments $\left({ }^{*} P<0.05\right.$, versus I).

2.10. Inhibition on AGE Formation In Vitro . AGE-modified BSA was prepared as previously described [23]. Briefly, BSA $(100 \mathrm{mg} / \mathrm{mL})$ was incubated under sterile conditions with $0.5 \mathrm{M}$ D-galactose in $0.2 \mathrm{M}$ phosphate-buffered saline (PBS, $\mathrm{pH} 7.4)$ at $37^{\circ} \mathrm{C}$ for eight weeks. For pine pollen or AG inhibition, samples were added with pine pollen $(1.2 \mathrm{mg} / \mathrm{mL}$ and $2.4 \mathrm{mg} / \mathrm{mL})$ or AG $(100 \mathrm{mM})$ and were incubated under identical conditions. The control BSA sample was incubated under identical conditions but without supplementation of D-galactose. Samples were dialyzed (10 kDa cut-off) against PBS and then the content of BSA-AGEs was determined by a commercial Elisa kit as described previously.

2.11. Data Analysis. All data listed in the figures or the tables were expressed as mean \pm SEM. One-way ANOVA analysis (SPSS 15.0) was used for data comparisons within multiple groups. In each case, $P<0.05$ was considered statistically significant.

\section{Results}

3.1. Effects of Pine Pollen on Cumulative Population Doublings in $2 B S$ Cells. In this study, we firstly observed the effects of pine pollen on replicative lifespan and biomarkers related to replicative senescence in human fetal lung diploid fibroblasts (2BS). Pine pollen significantly delayed replicative senescence of 2BS cells by at least 7 PDs (see Table 1). The two concentrations of pine pollen $(1 \mathrm{mg} / \mathrm{mL}$ and $2 \mathrm{mg} / \mathrm{mL}$ ) showed a similar gain in PDs. The growth rate of pine pollen treatment cells was dramatically increased compared to that of the control cells (Table 1). Meanwhile, pine pollen improved the proliferation of $2 \mathrm{BS}$ cells as demonstrated by using the Xcelligence system (Roche Applied Science, Basel, Switzerland), an impedance-based nondestructive assay of cell proliferation. Cells at PD30 incubated with pine pollen at $1 \mathrm{mg} / \mathrm{mL}$ and $2 \mathrm{mg} / \mathrm{mL}$ for $24-48 \mathrm{~h}$ showed a maximum $20 \%$ elevation on cell index (CI) compared with that of control (Figure 1). 
TABLE 2: Body weight and AGEs Levels.

\begin{tabular}{llcccc}
\hline \multirow{2}{*}{ Group } & Treatment & \multicolumn{2}{c}{ Body weight } & Serum AGEs (ng/mL) & \multicolumn{2}{c}{ Cerebral AGEs (ng/mg } \\
prot)
\end{tabular}

Note. C57BL/6J female mice (5-month-old, $n=10$ in each group) were treated daily with PBS (s.c, young control), D-galactose (D-gal, $100 \mathrm{mg} / \mathrm{kg}$, s.c), Dgal (100 mg/kg, s.c) with pine pollen (PP, 500, 1000, $1500 \mathrm{mg} / \mathrm{kg}$, ig) and aminoguanidine (AG, $100 \mathrm{mg} / \mathrm{kg}$, ig). AGEs levels at the end of the treatment were determined by a quantitative AGEs-ELISA kit. Statistical significant difference: ${ }^{*} P<0.05$, versus I; ${ }^{\Delta} P<0.05$, versus II.

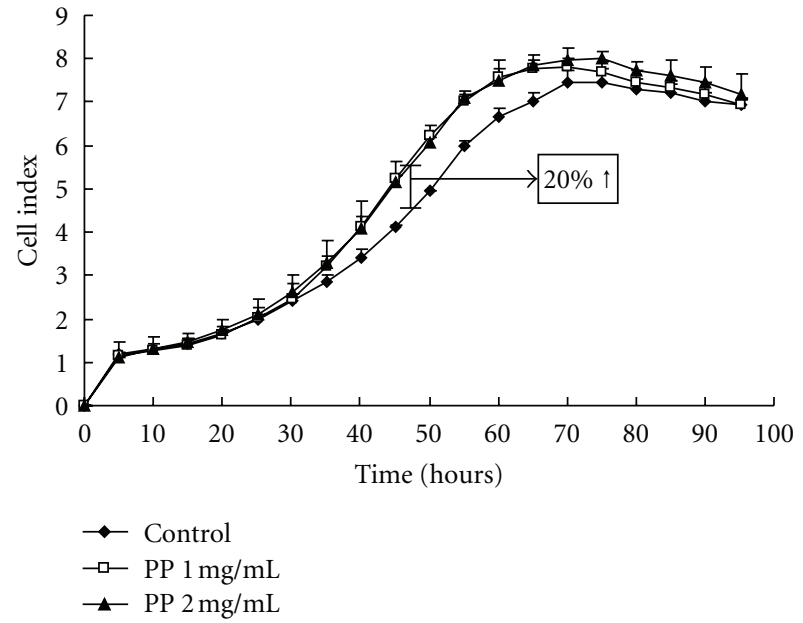

FIGURE 1: Line graph showing result of impedence-based cell proliferation assay (Xcelligence). The cell index (see Section 2) was plotted against time for the 2BS cells. Pine pollen (PP) was added $24 \mathrm{~h}$ after cell-seeding, and an approx. $20 \%$ elevation compared with the control was observed between $24-48 \mathrm{~h}$ under PP $(1 \mathrm{mg} / \mathrm{mL}$ and $2 \mathrm{mg} / \mathrm{mL}$ ) incubation.

3.2. Effects of Pine Pollen on SA- $\beta$-Gal Activity in $2 B S$ Cells. As expected, only sporadic SA- $\beta$-gal positive cells were observed in young control cells. As shown in Figure 2, the SA- $\beta$ gal positive rates of $1 \mathrm{mg} / \mathrm{mL}$ and $2 \mathrm{mg} / \mathrm{mL}$ pine pollen treatment PD55 cells were $27.2 \pm 4.3 \%$ and $25.3 \pm 4.9 \%$, respectively, which were much lower than that of PD55 control cells $(81.7 \pm 7.1 \%)$. These results indicate indirectly that the pine pollen delayed the population senescence of $2 \mathrm{BS}$ cells.

3.3. Effects of Pine Pollen on Expression of Senescence Associated Molecules in 2BS Cells. Activation of p53-p21 and p16$\mathrm{Rb}$ pathways results in replicative cellular senescence in human diploid fibroblasts $[17,24]$. Similar to our previous experiment, an elevated protein level of cyclin-dependent kinase $(\mathrm{CDK})$ inhibitors $\mathrm{p} 21^{\mathrm{Waf} 1}$ and $\mathrm{p} 16^{\mathrm{INK} 4}$ was observed in control late PD 2BS cells. However, the increased expression of senescence-associated molecules p53, p21, and p16 in late PD 2BS cells were significantly reversed to that of young control after pine pollen treatment (Figure 3). Moreover, emerging evidence revealed that the tumor suppressor phosphatase and tensin homolog PTEN and its downstream effector $\mathrm{p} 27^{\mathrm{Kip} 1}$ are also critical for replicative senescence $[24,25]$. Thus the effect of pine pollen on this signaling pathway was also checked in current experiment. Western blot results indicated that the protein expression of PTEN and $\mathrm{p} 27^{\mathrm{Kip} 1}$ was downregulated upon pine pollen treatment in late PD 2BS cells (Figure 3).

3.4. Effects of Pine Pollen on AGEs Formation in Mice. The facts that pine pollen retarding the aging process in $2 \mathrm{BS}$ cells promoted us to detect whether pine pollen has any antiaging effect on the D-galactose-induced aging model. Indeed, within the period of pine pollen treatment, no mouse showed a significant abnormality that could be detected by visual examination. All groups of mice gained weight normally throughout the study (Table 2). As expected, mice treated with D-galactose showed a remarkably increased level of serum and cerebral AGEs compared with control ones $(P<0.05$, Group II versus Group I, see Table 2$)$, and AG, a well-accepted AGEs formation inhibitor, significantly reversed the elevation of serum and cerebral AGEs in Dgalactose-treated mice $(P<0.05$, Group VI versus Group II, see Table 2). It should be noted that among the three different doses of pine pollen, low dosage $(500 \mathrm{mg} / \mathrm{kg})$ treatment showed best efficacy, which significantly blocked the increase of serum AGEs in D-galactose-treated mice $(P<0.05$, Group III versus Group II, see Table 2). Although a dose-dependent inhibitory effect of pine pollen on cerebral AGEs formation was observed in D-galactose-treated mice, the in vitro assay suggested that pine pollen had little inhibitory effect on the BSA-AGEs formation (Figure 4).

3.5. Effects of Pine Pollen on Neurological Activities in Mice. Next, we tested whether the decrement of serum and cerebral AGEs induced by pine pollen would reverse any aging effects, such as neurological activities, in D-galactose-induced aging model. Learning and memory abilities were examined by step-down test. D-galactose treatment significantly lowered the learning and memory activity of young mice compared with controls as evidenced by shortened latency of stepdown and elevated number of memory errors within five minutes. Consistent with previous studies [5], the lowered 


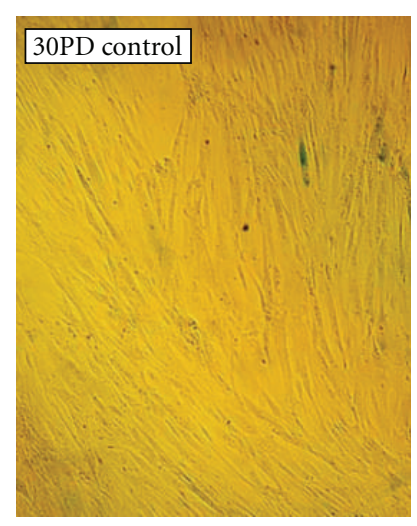

(a)

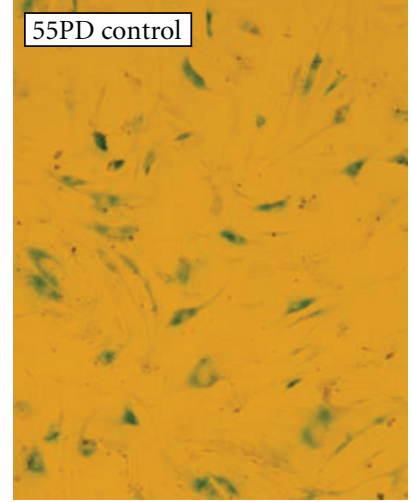

(b)

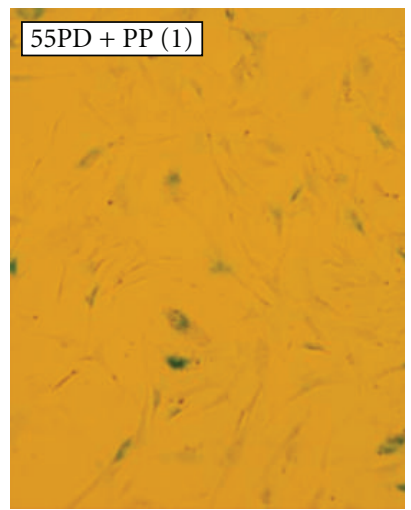

(c)

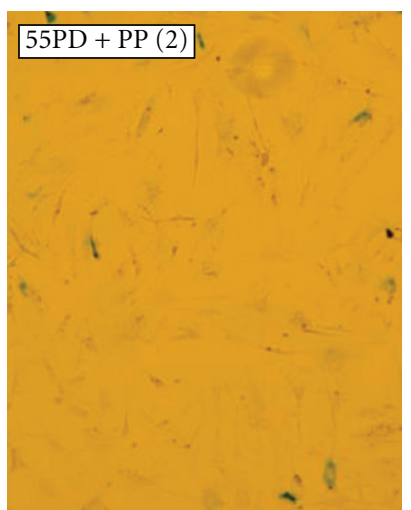

(d)

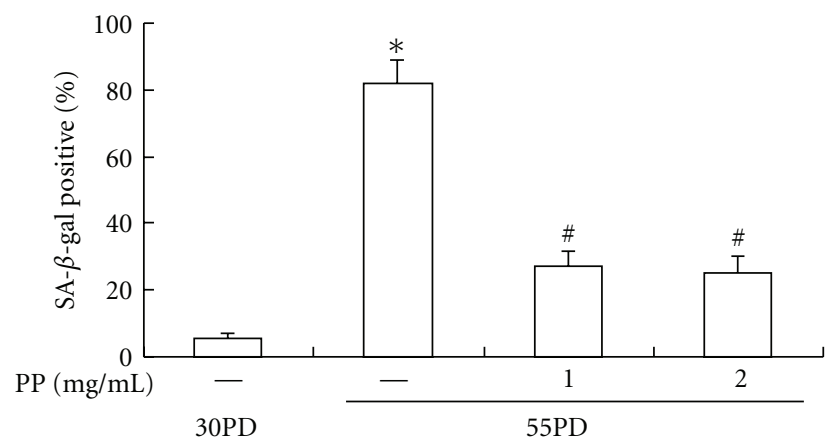

(e)

Figure 2: SA- $\beta$-gal staining of 2BS cells grown from PD30 in DMEM supplemented with $1 \mathrm{mg} / \mathrm{mL}$ or $2 \mathrm{mg} / \mathrm{mL}$ pine pollen (PP). Cells of none-confluent state were washed with PBS, fixed with 3\% formaldehyde, and stained in staining solution containing $1 \mathrm{mg} / \mathrm{mL} 5$-bromo-4chloro-3-indolyl- $\beta$-D-galactoside for $16 \mathrm{~h}$. 2BS cells at PD30 were set as young control. Cells were microphotographed at a magnification of $10 \times 10 .{ }^{*} P<0.01$ versus $30 \mathrm{PD}$ control group; ${ }^{\#} P<0.01$ versus $55 \mathrm{PD}$ control group.

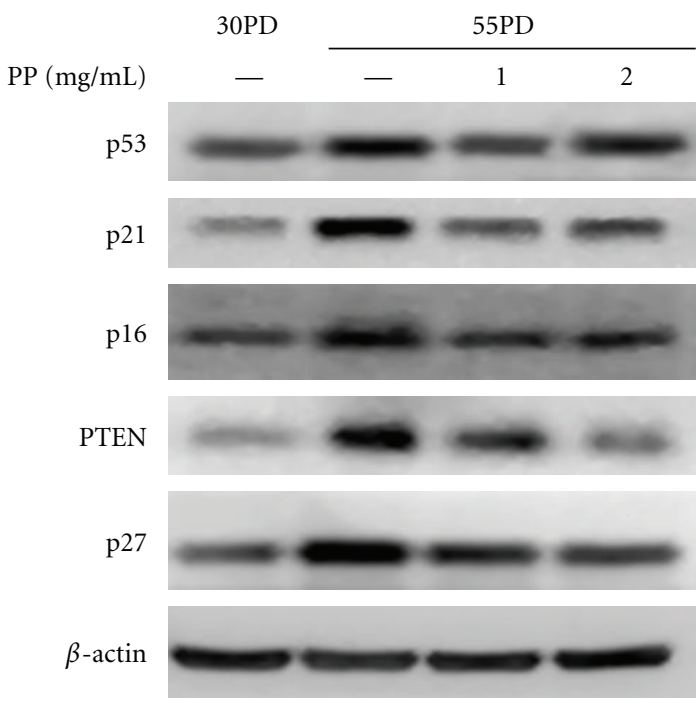

(a)

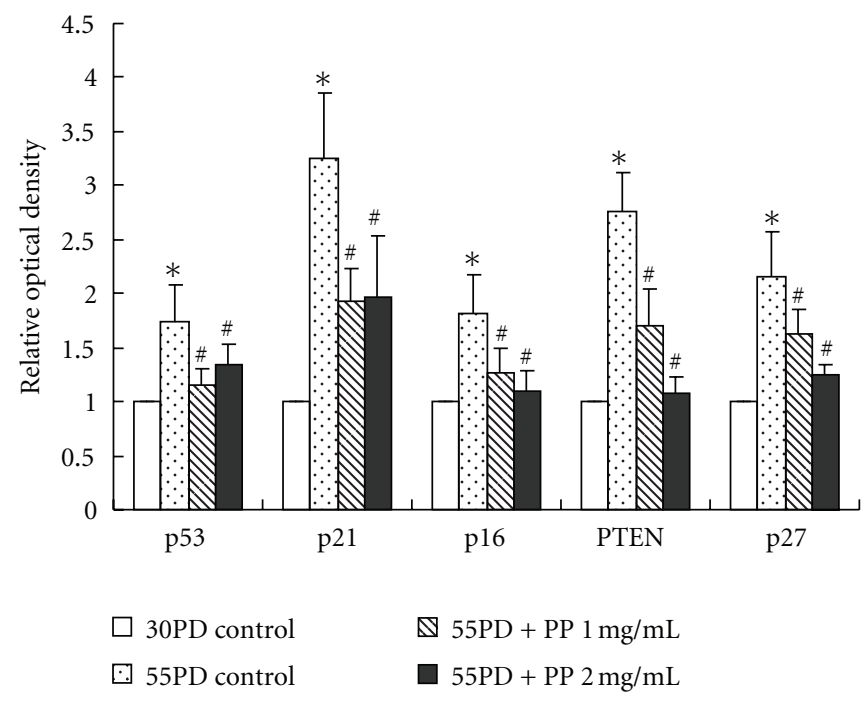

(b)

Figure 3: (a) Protein levels of p53, p21, p16, PTEN, and p27 in 2BS cells grown from PD30 in DMEM supplemented with $1 \mathrm{mg} / \mathrm{mL}$ or $2 \mathrm{mg} / \mathrm{mL}$ pine pollen (PP). Representative images were acquired from three different experiments. (b) Quantitative analysis of the protein levels of p53, p21, p16, PTEN, and p27. Bars represent relative protein levels counted as D1/D0 (the value for PD30 control was set as 1.0), where $D 0$ and $D 1$ stand for the optical density of $\beta$-actin ladder and sample ladder, respectively. The optical density for each ladder was calculated by Image J soft ware. Data were obtained from three independent experiments. ${ }^{*} P<0.05$ versus $30 \mathrm{PD}$ control group; ${ }^{\#} P<0.05$ versus 55PD control group. 
TABLE 3: Effect of pine pollen on SOD activity and MDA levels in mice.

\begin{tabular}{lccccc}
\hline Group & Treatment & $\begin{array}{c}\text { Serum MDA } \\
(\mathrm{nmol} / \mathrm{mL})\end{array}$ & $\begin{array}{c}\text { Cerebral MDA } \\
(\mathrm{nmol} / \mathrm{mg} \text { prot })\end{array}$ & Serum SOD (U/mL) & Cerebral SOD (Ul/mg prot) \\
\hline I & Young control & $7.74 \pm 1.04$ & $1.17 \pm 0.45$ & $82.91 \pm 4.25$ & $128.98 \pm 17.78$ \\
II & D-gal $(100 \mathrm{mg} / \mathrm{kg})$ & $17.66 \pm 7.93^{* *}$ & $2.90 \pm 1.28^{* *}$ & $69.18 \pm 6.00^{*}$ & $91.36 \pm 19.83^{*}$ \\
III & D-gal + PP $(500 \mathrm{mg} / \mathrm{kg})$ & $9.27 \pm 0.89^{\Delta}$ & $1.73 \pm 0.59^{\Delta}$ & $79.06 \pm 2.36$ & $109.27 \pm 12.91^{\Delta}$ \\
IV & D-gal + PP $(1000 \mathrm{mg} / \mathrm{kg})$ & $10.69 \pm 2.44^{\Delta}$ & $1.64 \pm 0.39^{\Delta}$ & $77.73 \pm 2.65$ & $110.76 \pm 24.02$ \\
V & D-gal + PP $(1500 \mathrm{mg} / \mathrm{kg})$ & $9.14 \pm 4.07^{\Delta}$ & $1.51 \pm 0.22^{\Delta \Delta}$ & $78.64 \pm 2.44$ & $111.71 \pm 16.59^{\Delta}$ \\
VI & D-gal + AG $(100 \mathrm{mg} / \mathrm{kg})$ & $5.89 \pm 2.65^{\Delta \Delta}$ & $1.48 \pm 0.24^{\triangle \Delta}$ & $79.80 \pm 2.75^{\Delta}$ & $120.88 \pm 25.91^{\Delta}$ \\
\hline
\end{tabular}

Note. C57BL/6J female mice (5-month-old, $n=10$ in each group) were treated daily with PBS (s.c, young control), D-galactose (D-gal, $100 \mathrm{mg} / \mathrm{kg}$, s.c), Dgal (100 mg/kg, s.c) with pine pollen (PP, 500, 1000, $1500 \mathrm{mg} / \mathrm{kg}$, ig), and aminoguanidine (AG, $100 \mathrm{mg} / \mathrm{kg}$, ig). SOD and MDA level in sera and brains were determined by commercial kits (Nanjing Jiancheng Bioengineering Institute, China) according to the manufacturer's protocol. Statistical significant difference: ${ }^{*} P<0.05$, versus I; ${ }^{\Delta} P<0.05$, versus II; ${ }^{*} P<0.01$, versus I; ${ }^{\Delta} \Delta P<0.01$, versus II.

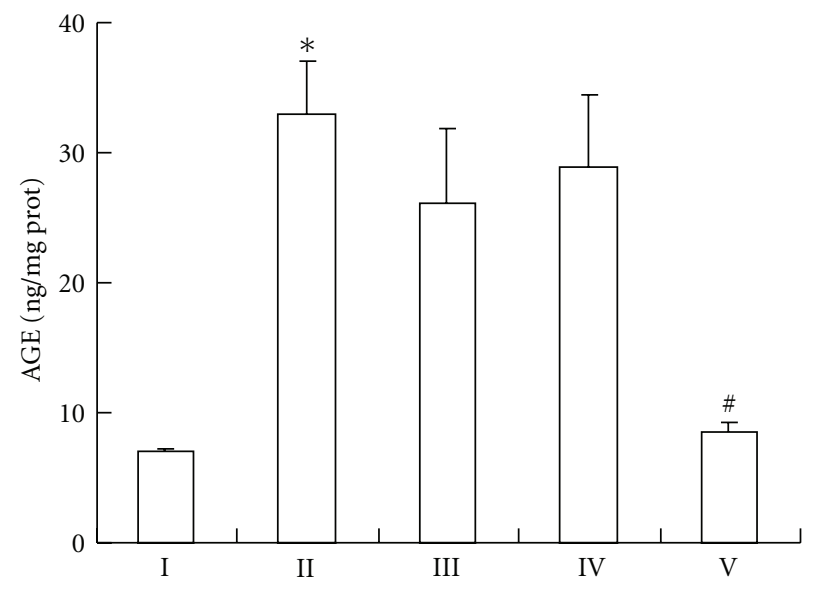

FIGURE 4: Effect of pine pollen on the BSA-AGEs formation in vitro. BSA alone at $100 \mathrm{mg} / \mathrm{mL}$ (I), BSA plus D-galactose at $0.5 \mathrm{M}$ (II), BSA plus D-galactose and pine pollen $(1.2 \mathrm{mg} / \mathrm{mL}$ and $2.4 \mathrm{mg} / \mathrm{mL}$, III and IV), and BSA plus D-galactose and AG at $100 \mathrm{mM}$ (V) were incubated at $37^{\circ} \mathrm{C}$ for eight weeks under sterile conditions. Samples were dialyzed ( $10 \mathrm{kDa}$ cut-off) against PBS and then the content of BSA-AGEs was determined by a commercial Elisa kit as described in Section 2. Data were results of three parallel experiments and were expressed as mean \pm SEM. Statistical significant difference: ${ }^{*} P<0.01$, versus I; ${ }^{\#} P<0.01$, versus II.

learning and memory activity of model mice can be reversed by AG treatment (Figure 5). The elevated number of memory errors within five minutes in D-galactose-treated young mice was also prevented by pine pollen treatment. Similarly, pine pollen reversed the shortened latency of step-down in $\mathrm{D}$-galactose-treated mice. Noticeably, the high dosage $(1500 \mathrm{mg} / \mathrm{kg}$ ) of pine pollen exhibited a comparable effect to that of AG treatment (see Figure 5).

3.6. Effect of Pine Pollen on Proinflammatory Cytokines Levels in Mice. It is well documented that aging is associated with increased circulating levels of proinflammatory cytokines. Increased levels of inflammatory serum markers in the elderly are associated with neurodegenerative diseases, such as dementia, Parkinson's disease [26]. As shown in Figure 6, the TNF- $\alpha$ and IL-6 levels in serum and cerebral were significantly elevated in D-galactose-treated mice in comparison to those in control group. Notably, pine pollen treatment significantly prevented the increment of cerebral IL- 6 which was comparable to that of AG treatment. A decreased trend of TNF- $\alpha$ level in sera and brains was also observed upon pine pollen treatment in model mice, though the difference was not statistically significant.

\subsection{Effects of Pine Pollen on the Antioxidant Enzymes Activity} and Lipid Peroxidation in Mice. It has been reported that $\mathrm{D}$-galactose treatment resulted in an elevation of oxidative stress both in vivo and in vitro [2, 27]. As expected, SOD activity was decreased, while the MDA level, an indicator of lipid peroxidation, increased in serum and brain in Dgalactose-treated young mice. However, additional treatment of pine pollen resulted in the increase of cerebral SOD activity and remarkable decrease of serum and cerebral MDA level in D-galactose treated mice (see Table 3). Consistent with previous study [5], a potent reversible effect of AG on SOD and MDA in this aging model was also observed (Table 3).

\section{Discussion}

Human diploid fibroblast cells can divide for only a limited number of times in vitro, a phenomenon known as replicative senescence [28]. The phenotypes of senescent 2BS cells included morphological changes, lower cell proliferation, positive SA- $\beta$-gal staining [16], and G1 cycle arrest which was mainly resulted from elevated protein levels of cyclindependent kinase (CDK) inhibitors $\mathrm{p} 21^{\text {Wafl }}$ and $\mathrm{p} 16^{\mathrm{INK} 4}$ [17]. Thus, we chose these senescence-associated markers to evaluate the antiaging effect of pine pollen in the current study. Our results demonstrated that Pine pollen delayed the replicative senescence of $2 \mathrm{BS}$ cells as evidenced by enhanced cell proliferation, decreased SA- $\beta$-Gal activity, and reversed expression of p53, p21, and p16 molecules in late PD cells (Figures 1, 2, and 3). Meanwhile, the expression of PTEN-p27 $7^{\text {Kip } 1}$ was also attenuated upon pine pollen treatment, which further supported our conclusions. The dosages 


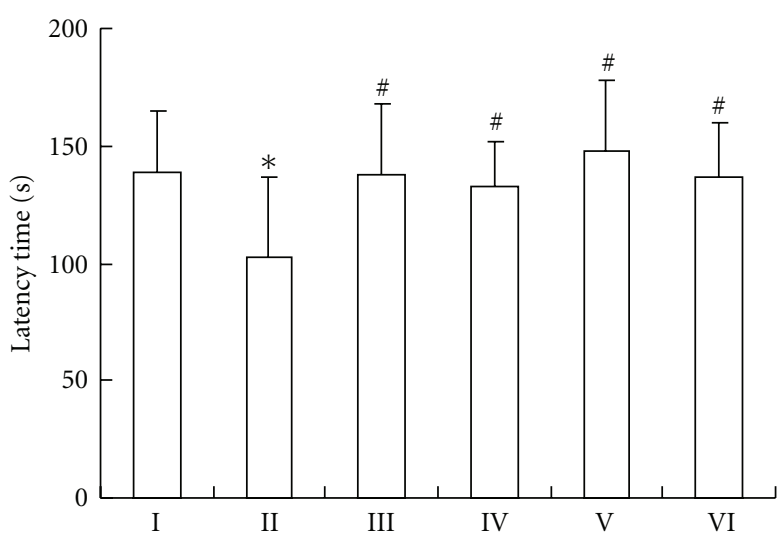

(a)

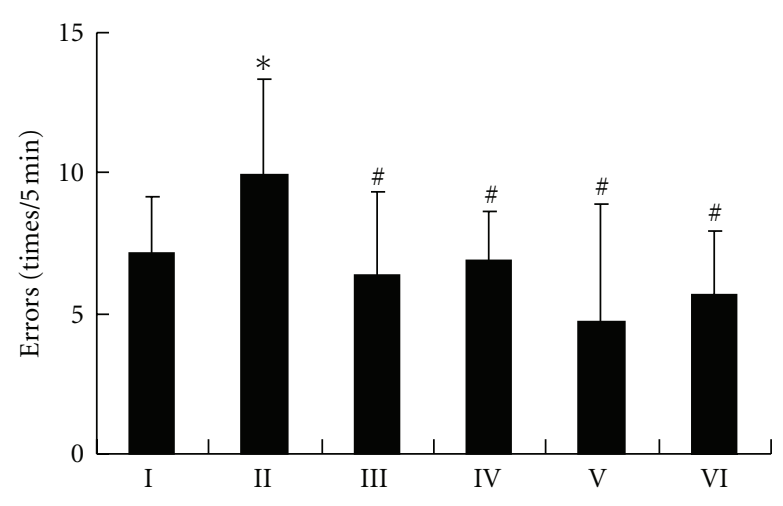

(b)

FIGURE 5: Latency time (a) and memory error rates (b) of young control (I), D-galactose alone(100 mg/kg) treated (II), D-galactose combined with pine pollen $(500,1000,1500 \mathrm{mg} / \mathrm{kg}$ ) treated (III, IV, V), and D-galactose combined with AG (100 mg/mg) treated (VI) mice. The step-down method was used to determine the latency time and memory error rates. Each mouse was trained for 5 min first to "remember" the system. Twenty-four hours later, mice were placed in the same cage and latency time (second), and the number of errors within five minutes was recorded. Data were results of ten animals for each group and expressed as mean \pm SEM. Statistical significant difference: ${ }^{*} P<0.05$, versus I; ${ }^{\#} P<0.05$, versus II.

of pine pollen $(1 \mathrm{mg} / \mathrm{mL} \& 2 \mathrm{mg} / \mathrm{mL})$ used in this study were much higher than that in previous studies $(10 \mu \mathrm{g} / \mathrm{mL})$ [14] as they used the ethanol extract of pine pollen (PPE), which was different from ours. We used the pine pollen powder rather than its extract. Since the abundance of active substances in our materials was lower than that of the ethanol extract of pine pollen, higher dosages have to be used in our experiment. However, the cell toxicity of pine pollen among $0 \sim 5 \mathrm{mg} / \mathrm{mL}$ was undetectable in 2BS cells according to an MTT assay (see Figure 7).

Though pine pollen showed an antiaging effect in vitro, whether it possesses any effect against aging in vivo remains elusive. Here we selected an accelerated aging model induced by $\mathrm{D}$-galactose for the in vivo study as this model resembles their aged control counterparts (16- to 24-monthold) both physiologically and pathologically and has been widely used for antiaging pharmacology research $[1,29,30]$. Our previous study demonstrated that D-galactose injection led to an accelerated aging phenotypes manifested by an increased serum AGEs level [5, 18]. Treatment of AGEs formation inhibitor aminoguanidine $(A G)$ and salidroside in D-galactose-induced aging mice could block most of the aging phenotypes, indicating that AGEs may account at least partially for the mechanism of the accelerated aging $[5,18]$.

In current experiment, the pine pollen showed different inhibitory effect on serum and cerebral AGEs formation in model mice. When the model mice were treated with a high dosage $(1500 \mathrm{mg} / \mathrm{kg})$ of pine pollen, the lowest level of AGEs in brains and a best reversal effect on lowered neurological activity were observed (Figure 5). However, pine pollen at a lower dosage $(500 \mathrm{mg} / \mathrm{kg})$ exhibited a best inhibitory efficacy on serum AGEs generation rather than the other two higher doses $(1000 \mathrm{mg} / \mathrm{kg}$ and $1500 \mathrm{mg} / \mathrm{kg}$ ). Besides, the in vitro assay revealed that pine pollen had little inhibitory effect on the BSA-AGEs formation, which was different from the role of AG, as this compound could inhibit the nonenzymatic glycation (NEG) both in vivo and in vitro (Table 2 and Figure 4). The possible reasons for the different role between pine pollen and AG were listed as below. Firstly, pine pollen contains various ingredients, including proteins, vitamins, enzymes and coenzymes, fats, flavonoids, nucleic acids, monosaccharides, polysaccharides, phospholipids, and other nutrients [12]. Flavonoids have been reported as potent inhibitors on AGEs formation [31, 32 ], while the ingredients of protein and monosaccharides are the substrates of nonenzymatic glycation which may accelerate the AGEs formation. Thus the inhibitory effect of pine pollen on AGEs formation would be partly offset by itself. Since higher dosages of pollen contain more nonenzymatic glycation substrates, a better inhibition of pine pollen on serum AGEs formation displayed under low dosage rather than that of higher dosages in vivo. Secondly, pine pollen showed an optimal inhibition on cerebral AGEs under high dose $(1500 \mathrm{mg} / \mathrm{kg})$; this may be induced by more active substances such as flavonoids in pine pollen going through into brain tissues. Thirdly, pine pollen may indirectly inhibit the AGEs formation in vivo by an antioxidant mechanism. Increased AGEs level can induce an elevated level of intracellular oxidative stress levels, which in turn promotes the nonenzymatic glycation [11, 33]. Effective removal of reactive oxygen species (ROS) may block the formation of AGEs. Indeed, the D-galactose-treated mice showed an elevation of oxidative stress in our experiment, and it was significantly reduced by pine pollen, as indicated by the declined MDA concentration, and reversion of decreased SOD activity (Table 3).

On the other hand, aging is associated with increased circulating levels of pro-inflammatory cytokines [26], which at least partly results from the increment of AGEs in elder persons as AGEs increase inflammation through binding 


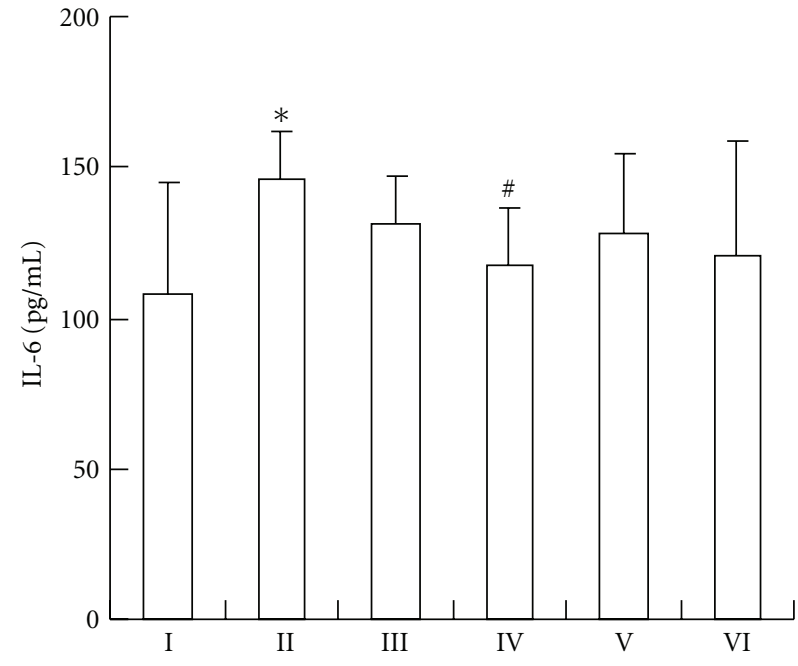

(a)

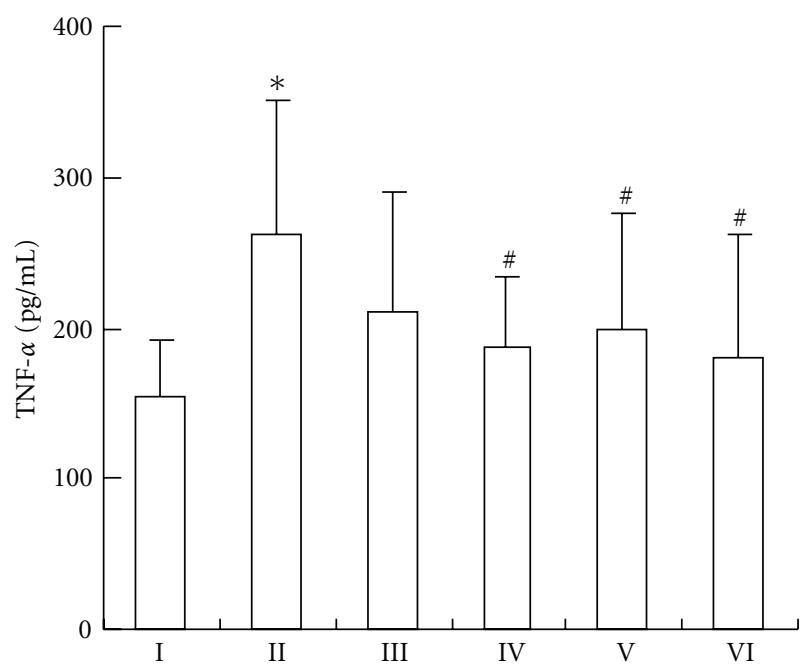

(c)

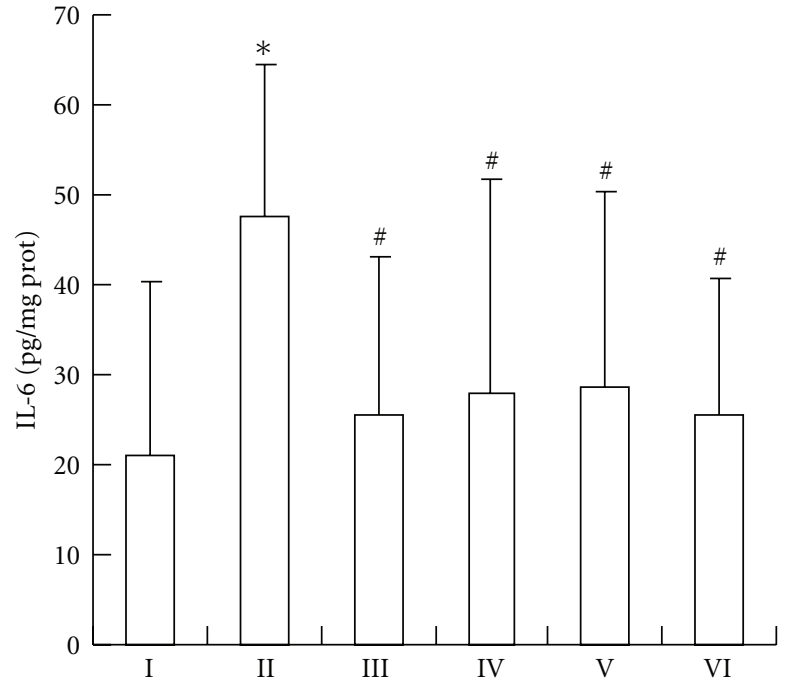

(b)

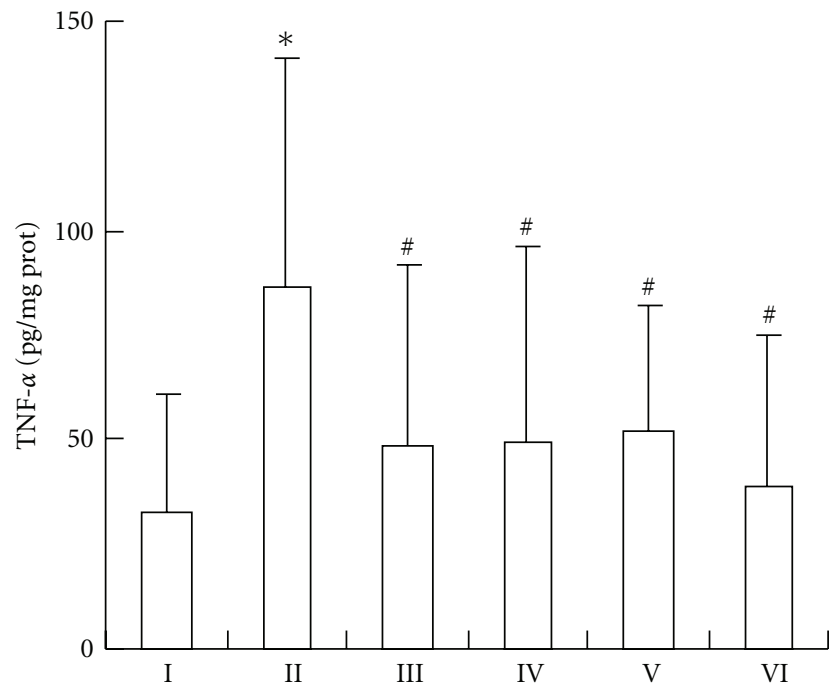

(d)

FIGURE 6: Proinflammatory cytokines levels of young control (I), D-galactose alone (100 mg/kg) treated (II), D-galactose combined with pine pollen $(500,1000,1500 \mathrm{mg} / \mathrm{kg}$ ) treated (III, IV, V), and D-galactose combined with AG (100 mg/mg) treated (VI) mice. IL-6 and TNF$\alpha$ in sera and brains were determined by quantitative ELISA kits. Data were results of ten animals for each group and expressed as mean \pm SEM. Statistical significant difference: ${ }^{*} P<0.05$, versus I; ${ }^{\#} P<0.05$, versus II.

with the receptor for AGEs (RAGEs). Inflammatory mediators that are upregulated through AGEs pathway include TNF- $\alpha$, IL-6, and C-reactive protein [34]. Thus a reduction of TNF- $\alpha$ and IL- 6 in our model mice treated with pine pollen was partly due to its inhibitory effect on nonenzymatic glycation as a similar result in model mice treated by the wellaccepted AGEs inhibitor AG was also observed (Figure 6).

However, our study might be limited by several aspects. As pine pollen is a complex mixture, it is necessary to clarify which kind of composition in pine pollen is responsible for its NEG inhibitory activity, and thus this beneficial effect could be optimized by using corresponding extraction from pine pollen. Further work regarding the relationship between the NEG inhibitory activity and antioxidant property of this drug is also needed.

\section{Conclusions}

Taken together, pine pollen is proved to delay the replicative senescence of human diploid fibroblasts and block D-galactose-induced increase of serum and cerebral AGEs level in model mouse, which may result in the reversal of $\mathrm{D}$ galactose-induced aging effects in both neural and inflammation system. It is possible that pine pollen exerts its antiaging 


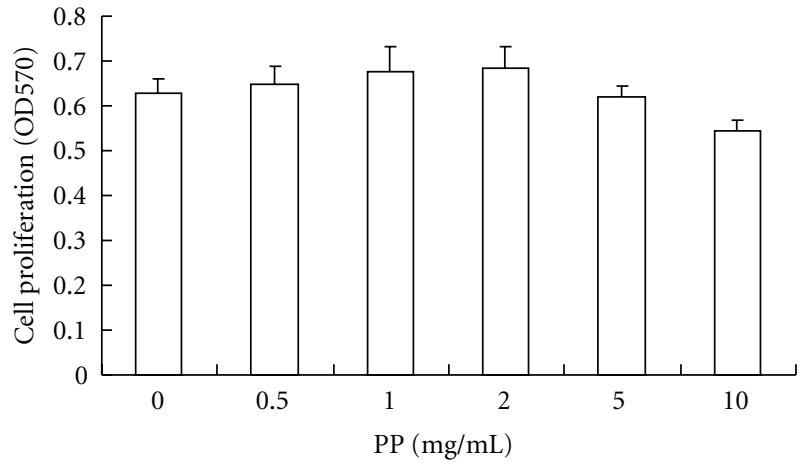

Figure 7: The cell toxicity of pine pollen was evaluated by the cell proliferation detected by the MTT assay. In brief, the 2BS cells were seeded in flat-bottomed 96-well microplates at the density of 3000 cells in $0.2 \mathrm{~mL}$ per well. After $20 \mathrm{~h}$, the cells were incubated in the culture medium containing various concentrations of pine pollen (PP) for $48 \mathrm{~h}$.Then $20 \mu \mathrm{L}$ MTT [3-(4,5)-dimethylthiahiazo (-z-y1)-3,5-diphenlytetrazoliumbromide] of $10 \mathrm{mg} / \mathrm{mL}$ was added to each well. After incubation for $4 \mathrm{~h}, 0.2 \mathrm{~mL}$ DMSO was added to stop reactions. The absorbance values of each well were determined spectrophotometrically at $570 \mathrm{~nm}$ using the microplate reader (BIOTEK, Rockville, MA, USA). A stimulatory rather than inhibitory effect of pine pollen under $0.5-5 \mathrm{mg} / \mathrm{mL}$ on $2 \mathrm{BS}$ cell proliferation was observed, which indicated its biosafety under such dosages.

effects at least partially by its NEG-inhibiting effect in vivo. Our work first directly proves the antiaging efficacy of the natural agent both in vivo and in vitro and thus inspires the new application for this drug in gerontological area.

\section{Acknowledgments}

This paper was supported by a fund from Ministry of Health of China (WKJ2011-2-014), a fund from Health Bureau of Zhejiang Province (11-CX01), the Science and Technology Department of Zhejiang Province Program (2008C33046), and Zhejiang Provincial Key Disciplinary Fields of Geriatrics Program. The authors would like to thank the Zhejiang Yalin Biotechnology Co. Ltd. (Hangzhou, China) for providing the pine pollen.

\section{References}

[1] H. Wei, L. Li, Q. Song, H. Ai, J. Chu, and W. Li, "Behavioural study of the D-galactose induced aging model in C57BL/6J mice," Behavioural Brain Research, vol. 157, no. 2, pp. 245-251, 2005.

[2] S. C. Ho, J. H. Liu, and R. Y. Wu, "Establishment of the mimetic aging effect in mice caused by D-galactose," Biogerontology, vol. 4, no. 1, pp. 15-18, 2003.

[3] D. Y. Yoo, W. Kim, C. H. Lee et al., "Melatonin improves Dgalactose-induced aging effects on behavior, neurogenesis, and lipid peroxidation in the mouse dentate gyrus via increasing pCREB expression," Journal of Pineal Research, vol. 52, no. 1, pp. 21-28, 2012.
[4] A. Kumar, A. Prakash, and S. Dogra, "Centella asiatica attenuates d-galactose-induced cognitive impairment, oxidative and mitochondrial dysfunction in mice," International Journal of Alzheimer's Disease, vol. 2011, Article ID 347569, 9 pages, 2011.

[5] X. Song, M. Bao, D. Li, and Y. M. Li, "Advanced glycation in Dgalactose induced mouse aging model," Mechanisms of Ageing and Development, vol. 108, no. 3, pp. 239-251, 1999.

[6] H. Vlassara, R. Bucala, and L. Striker, "Pathogenic effects of advanced glycosylation: biochemical, biologic, and clinical implications for diabetes and aging," Laboratory Investigation, vol. 70, no. 2, pp. 138-151, 1994.

[7] M. A. Smith, L. M. Sayre, V. M. Monnier, and G. Perry, "Radical AGEing in Alzheimer's disease," Trends in Neurosciences, vol. 18, no. 4, pp. 172-176, 1995.

[8] J. Tian, K. Ishibashi, K. Ishibashi et al., "Advanced glycation endproduct-induced aging of the retinal pigment epithelium and choroid: a comprehensive transcriptional response," Proceedings of the National Academy of Sciences of the United States of America, vol. 102, no. 33, pp. 11846-11851, 2005.

[9] R. D. Semba, E. J. Nicklett, and L. Ferrucci, "Does accumulation of advanced glycation end products contribute to the aging phenotype?" Journals of Gerontology A, vol. 65, no. 9, pp. 963-975, 2010.

[10] E. R. Stadtman, "Protein oxidation and aging," Science, vol. 257, no. 5074, pp. 1220-1224, 1992.

[11] S. Y. Li, V. K. Sigmon, S. A. Babcock, and J. Ren, "Advanced glycation endproduct induces ROS accumulation, apoptosis, MAP kinase activation and nuclear O-GlcNAcylation in human cardiac myocytes," Life Sciences, vol. 80, no. 11, pp. 10511056, 2007.

[12] X. He, X. Sun, and Z. Yu, "Effective components and pharmacological function of pine pollen," Journal of Northeast Forestry University, vol. 35, no. 9, pp. 78-80, 2007.

[13] K. H. Lee and E. M. Choi, "Effect of pine pollen extract on experimental chronic arthritis," Phytotherapy Research, vol. 23, no. 5, pp. 651-657, 2009.

[14] K. H. Lee, A. J. Kim, and E. M. Choi, "Antioxidant and antiinflammatory activity of pine pollen extract in vitro," Phytotherapy Research, vol. 23, no. 1, pp. 41-48, 2009.

[15] J. Li, Z. Zhang, and T. Tong, "The proliferative response and anti-oncogene expression in old 2BS cells after growth factor stimulation," Mechanisms of Ageing and Development, vol. 80, no. 1, pp. 25-34, 1995.

[16] P. Wang, Z. Zhang, X. Ma et al., "HDTIC-1 and HDTIC-2, two compounds extracted from Astragali Radix, delay replicative senescence of human diploid fibroblasts," Mechanisms of Ageing and Development, vol. 124, no. 10-12, pp. 1025-1034, 2003.

[17] G. X. Mao, Y. Wang, Q. Qiu et al., "Salidroside protects human fibroblast cells from premature senescence induced by $\mathrm{H}_{2} \mathrm{O}_{2}$ partly through modulating oxidative status," Mechanisms of Ageing and Development, vol. 131, no. 11-12, pp. 723-731, 2010.

[18] G. X. Mao, H. B. Deng, L. G. Yuan, D. D. Li, Y. Y. Y. Li, and Z. Wang, "Protective role of salidroside against aging in a mouse model induced by D-galactose," Biomedical and Environmental Sciences, vol. 23, no. 2, pp. 161-166, 2010.

[19] Z. Tang, Z. Zhang, Y. Zheng, M. J. Corbley, and T. Tong, "Cell aging of human diploid fibroblasts is associated with changes in responsiveness to epidermal growth factor and changes in HER-2 expression," Mechanisms of Ageing and Development, vol. 73, no. 1, pp. 57-67, 1994. 
[20] D. P. Mangiameli, J. A. Blansfield, S. Kachala et al., "Combination therapy targeting the tumor microenvironment is effective in a model of human ocular melanoma," Journal of Translational Medicine, vol. 5, article 38, 2007.

[21] G. P. Dimri, X. Lee, G. Basile et al., "A biomarker that identifies senescent human cells in culture and in aging skin in vivo," Proceedings of the National Academy of Sciences of the United States of America, vol. 92, no. 20, pp. 9363-9367, 1995.

[22] S. Ahmadi, N. Malekmohammadi, and M. R. Zarrindast, "Repeated histamine pretreatment decreased amnesia induced by post-training administration of the drug in a step-down inhibitory avoidance test in mice," Archives of Iranian Medicine, vol. 13, no. 3, pp. 209-216, 2010.

[23] Z. Makita, H. Vlassara, A. Cerami, and R. Bucala, "Immunochemical detection of advanced glycosylation end products in vivo," Journal of Biological Chemistry, vol. 267, no. 8, pp. 51335138, 1992.

[24] F. Bringold and M. Serrano, "Tumor suppressors and oncogenes in cellular senescence," Experimental Gerontology, vol. 35, no. 3, pp. 317-329, 2000.

[25] K. Alexander and P. W. Hinds, "Requirement for p27KIP1 in retinoblastoma protein-mediated senescence," Molecular and Cellular Biology, vol. 21, no. 11, pp. 3616-3631, 2001.

[26] M. De Martinis, C. Franceschi, D. Monti, and L. Ginaldi, "Inflamm-ageing and lifelong antigenic load as major determinants of ageing rate and longevity," FEBS Letters, vol. 579, no. 10, pp. 2035-2039, 2005.

[27] M. Lei, X. Hua, M. Xiao, J. Ding, Q. Han, and G. Hu, "Impairments of astrocytes are involved in the d-galactoseinduced brain aging," Biochemical and Biophysical Research Communications, vol. 369, no. 4, pp. 1082-1087, 2008.

[28] L. Hayflick, "The limited in vitro lifetime of human diploid cell strains," Experimental Cell Research, vol. 37, no. 3, pp. 614636, 1965.

[29] X. Cui, P. Zuo, Q. Zhang et al., "Chronic systemic Dgalactose exposure induces memory loss, neurodegeneration, and oxidative damage in mice: protective effects of R- $\alpha$-lipoic acid," Journal of Neuroscience Research, vol. 84, no. 3, pp. 647654, 2006.

[30] G. Guoqing and X. fuben, "Study of aging model in mice," Journal of China Pharmaceutical University, vol. 22, no. 2, pp. 101-103, 1991.

[31] S. Pashikanti, D. R. de Alba, G. A. Boissonneault, and D. Cervantes-Laurean, "Rutin metabolites: novel inhibitors of nonoxidative advanced glycation end products," Free Radical Biology and Medicine, vol. 48, no. 5, pp. 656-663, 2010.

[32] P. Urios, A. M. Grigorova-Borsos, and M. Sternberg, "Flavonoids inhibit the formation of the cross-linking AGE pentosidine in collagen incubated with glucose, according to their structure," European Journal of Nutrition, vol. 46, no. 3, pp. 139-146, 2007.

[33] V. P. Reddy and A. Beyaz, "Inhibitors of the Maillard reaction and AGE breakers as therapeutics for multiple diseases," Drug Discovery Today, vol. 11, no. 13-14, pp. 646-654, 2006.

[34] G. Basta, "Receptor for advanced glycation endproducts and atherosclerosis: from basic mechanisms to clinical implications," Atherosclerosis, vol. 196, no. 1, pp. 9-21, 2008. 


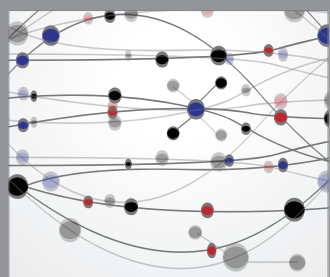

The Scientific World Journal
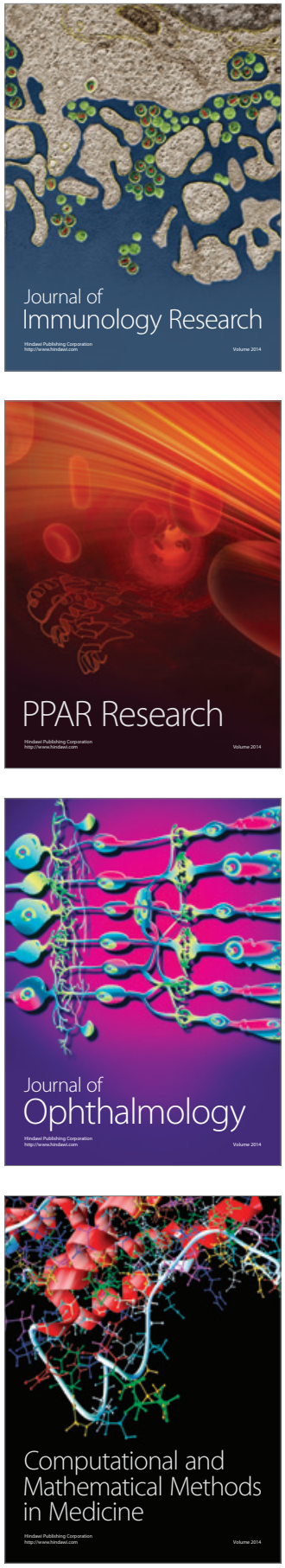

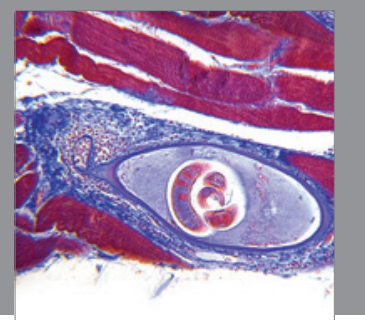

Gastroenterology

Research and Practice
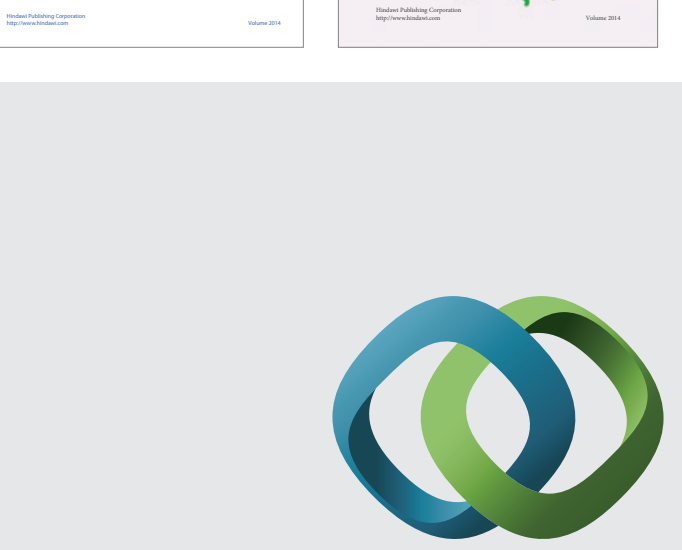

\section{Hindawi}

Submit your manuscripts at

http://www.hindawi.com
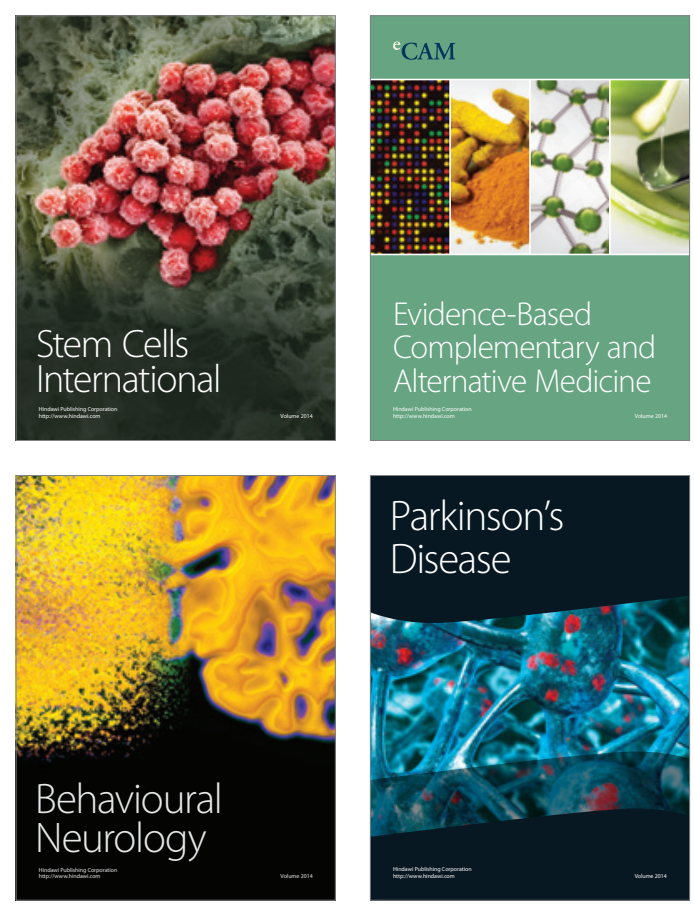

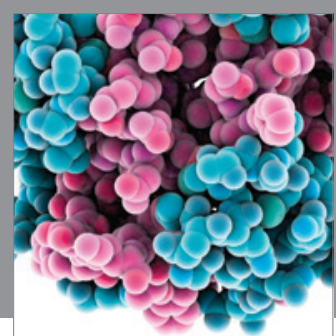

Journal of
Diabetes Research

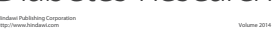

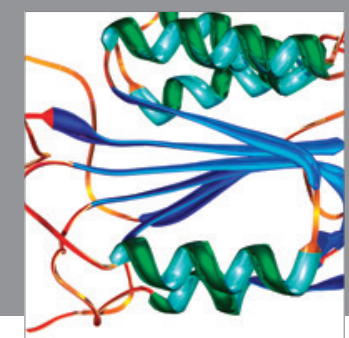

Disease Markers
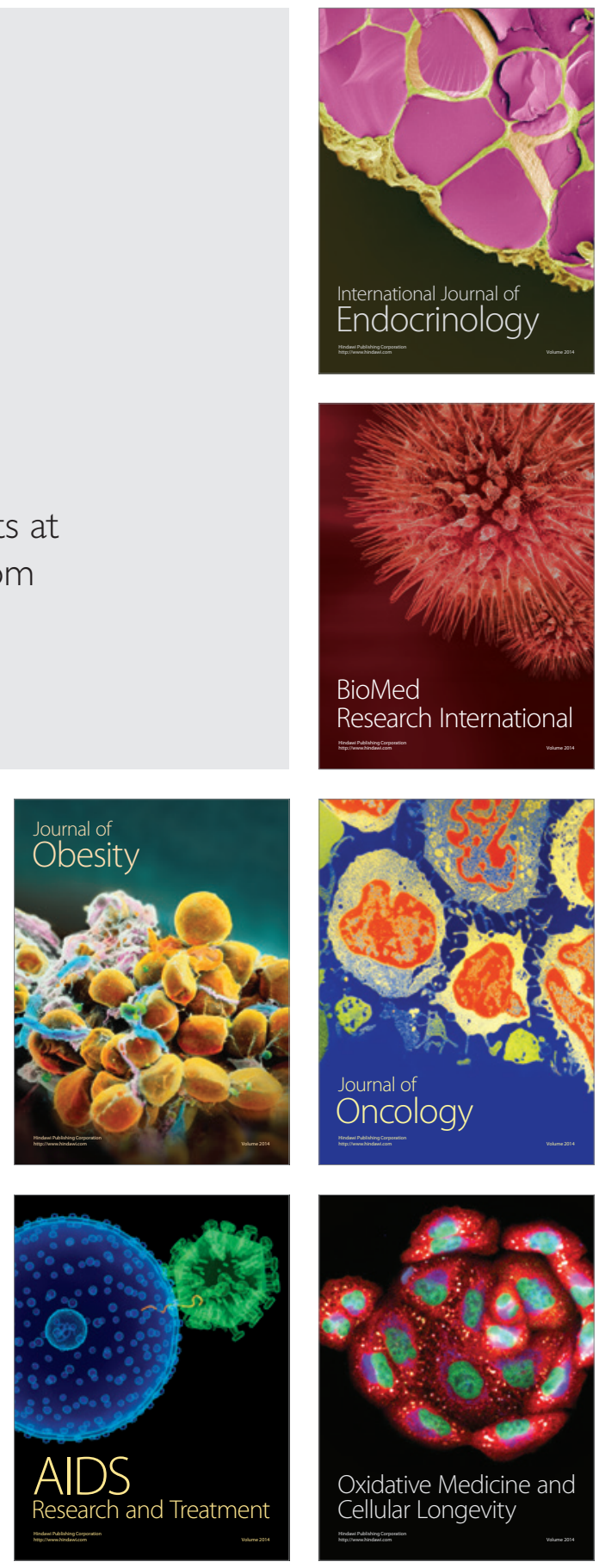